\title{
PENERAPAN SELF COMPACTING CONCRETE (SCC) PADA BETON MUTU NORMAL
}

\author{
Oleh: Yogie Risdianto *)
}

\begin{abstract}
Abstrak
Self Compacting Concrete (SCC), merupakan sebuah aplikasi dalam dunia teknologi beton, memiliki keunggulan Flowability, Passingability, Fillingability dan mampu meningkatkan kuat tekan beton, sehingga dapat diaplikasikan dengan baik dalam dunia usaha beton. Dalam penelitian ini SCC dengan menggunakan bahan tambahan berupa Superplasticizer berjenis Conplast SP430 dengan penambahan komposisi Conplast SP430 yang bervariasi yaitu 0.5; 1; 1.5; 2 liter pada campuran beton.

Pengujian Workability dilakukan dengan menggunakan alat Slump Cone, V-Funnel untuk pengujian tingkat Fillingability, sedangkan L-Shaped Box digunakan untuk pengujian tingkat Passingability pada campuran beton. Dari tes Workability hasil penelitian menunjukkan penggunaan Conplast SP430 sebesar 2 liter sudah mampu mencapai kriteria dari SCC.

Dari tes kuat tekan beton hasil penelitian menunjukkan penggunaan Conplast SP430 sebesar 1 liter mengalami kenaikan kuat tekan beton sebesar $26.88 \%$ dari benda uji yang dianggap kontrol yaitu tanpa penambahan Conplast SP430 pada umur 28 hari. Untuk pengujian kuat tekan saat beton berumur 7 hari rata-rata mencapai $312.88 \mathrm{~kg} / \mathrm{cm} 2$. Sedangkan untuk umur beton 28 hari, rata-rata kuat tekan beton yang dicapai sebesar $356.82 \mathrm{~kg} / \mathrm{cm} 2$.
\end{abstract}

Kata Kunci : Self Compacting Concrete, Workability, kuat tekan beton.

\section{PENDAHULUAN}

Self Compacting Concrete (SCC), merupakan suatu hasil riset di jepang pada awal tahun 80an dengan menghasilkan suatu prototype yang cukup sukses pada tahun 1988. Dihadapkan pada kenyataan lapangan berupa keterbatasan skill para pekerja dalam pengerjaan pemadatan beton, semakin meningkatnya kebutuhan para designer untuk mewujudkan suatu struktur dengan tulangan yang komplek, disertai dengan mutu besi tulangan yang tinggi menjadi latar belakang pengembangan dari 'beton spesial' ini.

SCC adalah beton berkinerja tinggi, yaitu yang dapat mengalir dengan sendiri, berdaya tahan yang baik, dan memiliki kekuatan yang tinggi. Tetapi semua semua hal tersebut hanya dapat dicapai apabila pada campuran mengalami deformability yang tinggi dan tidak mengalami segregasi.

\section{Tujuan}

Tujuan dari Penelitian ini adalah:

1. Mengetahui komposisi Mix Design SCC secara optimal pada beton mutu normal.

2. Mengetahui tingkat Flowability, dan Workability dengan penambahan Conplast SP430 terhadap campuran beton.
3. Mengetahui kuat tekan yang dihasilkan dari penambahan Conplast SP430 terhadap Mix Design SCC.

4. Mengetahui penggunaan dan penerapan metode SCC pada beton mutu normal.

\section{KAJIAN PUSTAKA}

Self Compacting Concrete (SCC) sebagai alternative campuran beton yang memiliki pori-pori kecil, membutuhkan material yang memiliki karakteristik yang sedikit berbeda dari beton konvensional. Disamping agregat kasar yang digunakan memiliki ukuran yang relative lebih kecil, pada SCC dipergunakan Superplasticizer jenis Conplast SP430.

\section{Mix Design beton Self Compacting} Concrete (SCC).

Untuk membuat campuran SCC yang baik, metode Mix Design yang biasa tidak dapat lagi dipergunakan. Karena itu pada tahun 1995, Okamura dan Ozawa (1995) mengusulkan metode Mix Design yang sederhana dengan mengacu pada material yang sudah tersedia pada pabrik beton ready-mix.

\footnotetext{
*) Dosen Teknik Sipil

Universitas Negeri Surabaya
} 
Kadar agregat kasar dan agregat halus ditentukan terlebih dahulu dan pemadatan mandiri dapat didapatkan dengan mengatur faktor air binder dan dosis Superplasticizer saja.

Spesifikasinya antara lain :

1) Agregat kasar yang digunakan adalah $40 \%$ volume solid, agar mortar dapat melewati sela-sela dari agregat kasar yang kurang rapat.

2) Volume agregat halus ditetapkan hanya $60 \%$ dari volume mortar, yang bertujuan untuk mengisi void dari agregat kasar.

3) Dosis Superplasticizer dan faktor air binder ditentukan setelahnya untuk mendapatkan pemadatan secara mandiri.

Pada beton konvensional, faktor air semen (f.a.s) digunakan untuk memastikan kekuatan akhirnya sementara pada beton SCC, faktor air semen harus digunakan untuk mendapatkan pemadatan secara mandiri, karena faktor ini sangat mempengaruhi sifat beton segarnya, dan kekuatannya hanya sebagai bagian kontrol kualitas.

Campuran beton SCC adalah di design dan di uji untuk memenuhi tuntunan dari proyek. Contohnya, proses memompa. Sifat beton yang dapat dipompa sangat diperhatikan. Beton Self Compacting digunakan di konstruksi jembatan suspensi Akhashi Kaiko. Beton Self Compacting dicampur, ditempat pekerjaan, dipompa melewati sistem pipa untuk lokasi pelabuhan $200 \mathrm{~m}$. SCC dijatuhkan dari ketinggian sekitar lima meter tanpa ada pemisahan agregat untuk beton masif. Konstruksi beton Self Compacting mengurangi waktu konstruksi jembatan dari 2,5 tahun menjadi 2 tahun. Dan beberapa negara membuat mix design SCC yang berbeda-beda, yang bertujuan menyesuaikan dari wilayah negara tersebut dengan mutu yang sesuai dengan rencana.

\section{Mix Design DOE (British Departement of Environment).}

Seperti pada beton konvensional, SCC juga mengacu pada salah satu standart beton yang umum. Pada penelitian ini standart Mix Design umum digunakan adalah standart Mix Design DOE. Dari standart Mix Design DOE yang ada, digunakan Standart Mix Design beton yang menggunakan pfa (pulverised fuel ash). (Nugraha Paulus Ir. M.Eng, Teknologi Beton, 1989).

\section{Mix Design Okamura.}

Penelitian metode Self Compacting Concrete (SCC) oleh Okamura ini dilakukan School of Enginering di University of Tokyo dan mulai diseminarkan pada 6 november 1996 di New Orleans. Sample Mix Design dari Okamura merupakan Mix Design yang sederhana dalam penentuan awal dari komposisi tiap bahan. Komposisi-komposisi yang di usulkan adalah sebagai berikut (RILEM Publications S.A.R.L., Self Compacting Concrete, 1999)

1. Agregat kasar dibatasi jumlahnya sampai kurang lebih $40 \%$ dari volume padatnya.

2. Pembatasan jumlah agregat halus kurang lebih $60 \%$ dari volume mortar.

3. Water-cement ratio dalam volume beton diperkirakan antara 0.9-1.0, tergantung dari kandungan yang terdapat semen.

4. Dosis dari admixture yang telah ditetapkan dan penentuan akhir dari water-powder ratio untuk menyakinkan akan terjadinya self compactibility.

Metode mix design dari Okamura secara umum dapat dilihat pada gambar 1. (Morita, S., Journal of Advanced Concrete Teknology, 2003).

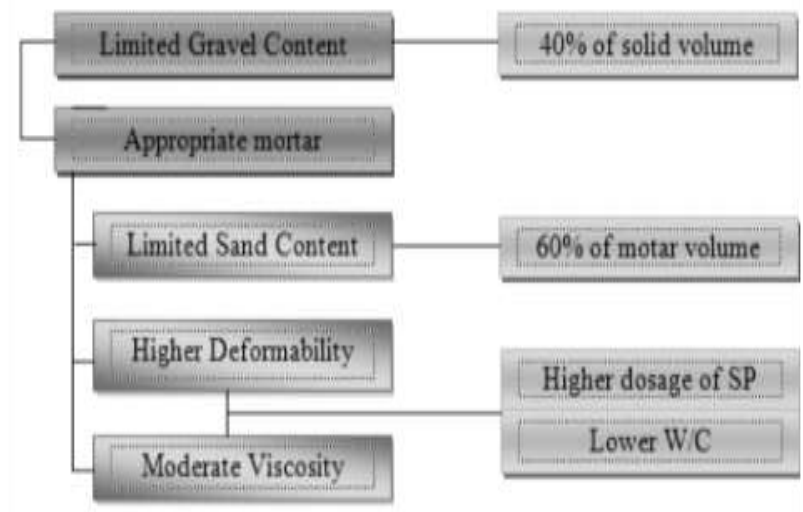

Gambar 1. Diagram Mix Design Okamura

\section{Penyesuaian metode Mix Design DOE dan Mix Design Okamura. \\ Untuk mendapatkan Mix Design Self} Compacting Concrete yang optimal maka dilakukan penyesuaian-penyesuaian yang dilakukan antara lain :

1. Karena efek dari Superplasticizer yang digunakan, maka dilakukan penyesuaian dari besarnya air yang digunakan (freewater content).

2. Perbandingan komposisi antara agregat halus dan agregat kasar mengikuti simple Mix Design Okamura. 
Di dalam pengujiannya, Self Compacting Concrete sebagai suatu varian beton yang memiliki karakteristik sebagai beton yang memiliki tingkat workabilitas yang baik, maka SCC harus memenuhi kriteria-kriteria (Efnarc Association, Spesification and Guideliness for self compacting concrete, 2002).

1. Kemampuan campuran beton untuk mengisi ruangan (Filling Ability).

2. Kemampuan campuran beton untuk melewati elemen struktur dengan tulangan yang rapat (Passing Ability).

3. Ketahanan beton terhadap segregasi (segregation-resistence).

1) Pengujian Workability Self Compacting Concrete.

Untuk penelitian SCC ini kami menggunakan beberapa alat yang mewakili pengujian untuk memenuhi ketiga kriteria. Alat-alat itu antara lain:

\section{a. Slump Cone.}

Pengujian Slump Cone berbeda dengan pengujian Slump yang digunakan pada beton konvensional, pada pengujian Slump Cone ini alat yang digunakan terbalik sehingga diameter yang kecil diletakkan dibawah dan diameter yang besar terletak diatas. Alat uji Slump Cone dapat dilihat pada gambar 2 .

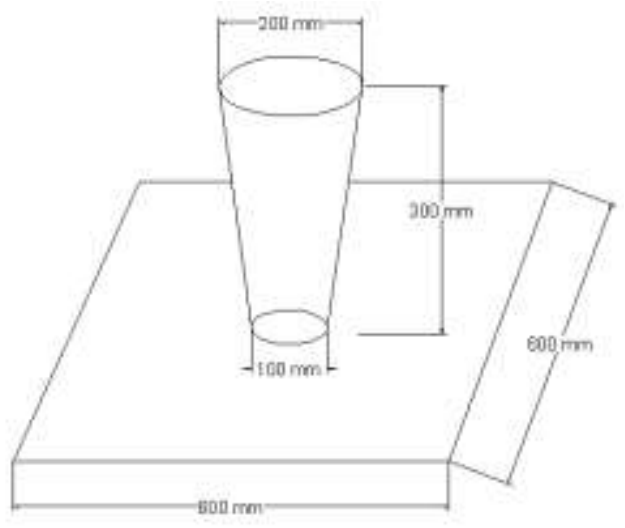

Gambar 2. Slump Cone

Pengujian dengan Slump Cone dilakukan untuk mengetahui seberapa besar kemampuan campuran beton untuk menggisi ruangan (Filling ability). Hal ini dapat dilihat dari diameter lingkaran campuran beton untuk mengukur Fillingability dari campuran beton.

Metode pengujian dengan Slump Cone merupakan metode yang simple, cepat dan mudah untuk dilakukan di lapangan. Metode pengujian Slump Cone ini tidak dapat mengindikasikan kemampuan beton untuk menahan segregasi. Pengujian Slump Cone sangat menguntungkan untuk menjaga konsistensi campuran beton yang direncanakan dan dibuat.

$\mathrm{Di}$ dalam pengujian dengan menggunakan slump cone, terdapat suatu batasan-batasan dimana kategori SCC dikatakan masuk dalam syarat Fillingability yang baik. Batasan dalam alat uji Slump Cone, campuran beton dikategorikan SCC harus mampu mencapai diameter $50 \mathrm{~cm}$ dalam waktu kurang dari 6 detik dan apabila melebihi dari 6 detik maka beton tersebut bukan kategori SCC. (Setiawan, A., Self Compacting Concrete: Fenomena Baru Dunia Teknologi Beton, 2001)

\section{b. V-Funnel Test.}

Metode ini dikembangkan pertama kali di Jepang dan digunakan oleh Ozawa. Alat ini terdiri dari corong berbentuk $\mathrm{V}$ yang dapai dilihat pada gambar 3 .

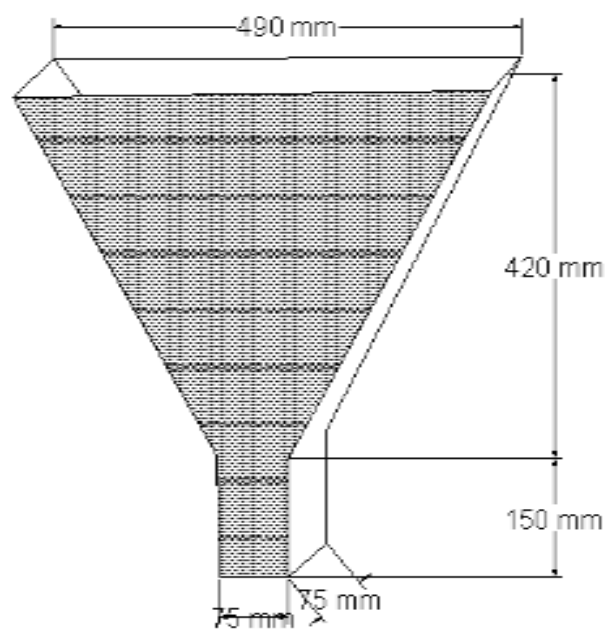

Gambar 3. V-Funnel

Pengujian dengan menggunakan V-Funnel berguna untuk mengukur flowabilitas dari campuran beton, dimana kemampuan campuran beton untuk mengisi ruang (Filling Ability) dapat dilihat. Selain itu penggujian dengan menggunakan $V-$ Funnel Test dapat digunakan untuk mengetahui kemampuan campuran beton untuk menahan segregasi (Segregation Resistance).

Desain dari alat $V$-Funnel Test sendiri dapat mengindikasikan campuran apabila terlalu banyak komposisi agregat kasar pada 
campuran beton maka waktu yang diperlukan campuran untuk mengalir semakin lama. Campuran beton yang dikategorikan SCC harus mampu mencapai waktu 8-12 detik (Efnarc Association, Spesification and Guideliness for Self Compacting Concrete, 2002)

\section{c. L-Shaped Box.}

Metode ini dibuat berdasarkan standard jepang yang diaplikasikan untuk beton untuk konstruksi bawah air, diperkenalkan oleh petersson. Alat ini berbentuk huruf $L$ dan terbuat dari Plat besi. Pada alat ini, antara arah horizontal dengan vertikal dipasang pintu penutup yang cara membukanya dengan menarik ke arah atas dan diberikan alat tambahan di depannya yang berupa halangan dari tulangan baja, halangan ini berfungsi untuk mengkondisikan sesuai dengan kesdaan di lapangan. Alat uji LShaped Box dapat dilihat gambar 4.

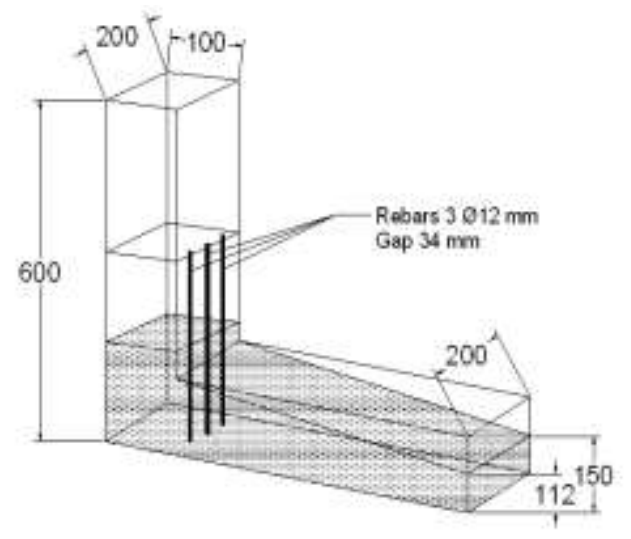

Gambar 4. L-Shaped Box

Pengujian dengan mengggunakan metode $L$-Shaped Box ini ditunjukkan terdapat suatu batasan-batasan dimana kategori SCC dikatakan masuk dalam syarat
Passingability yang baik. Batasan dalam alat uji L-Shaped Box, campuran beton yang dikategorikan SCC harus mampu memenuhi syarat $\mathrm{H} 2 / \mathrm{H} 1>0,8$ (RILEM Publications S.A.R.L., Self Compacting Concrete, 1999).

\section{METODOLOGI PENELITIAN}

Penentuan awal komposisi tiap bahan sebagai berikut :

1. Jumlah total agregat halus $1108 \mathrm{~kg} / \mathrm{m}^{3}$.

2. Jumlah total agregat kasar $739 \mathrm{~kg} / \mathrm{m}^{3}$.

3. Jumlah semen $357 \mathrm{~kg} / \mathrm{m}^{3}$.

4. Jumlah air yang diberikan adalah sebesar $225 \mathrm{~kg} / \mathrm{m}^{3}$. Dan pengurangan air sebesar $10 \%$ jika ada penambahan Conplast SP430.

5. Besarnya dosis Superplasticizer Conplast SP430 yang diberikan 0,5; 1; 1,5; 2 liter per $100 \mathrm{~kg}$ berat semen.

Pada penelitian SCC ini terdapat banyak veriabel yang memepengeruhi workability dan kuat tekan beton. Dan untuk menyederhanakan variasi campuran mix design selanjutnya dan melihat pengeruh masing-masing variabel.

a. Variabel Bebas (Independent Variable) Tingkat Passingability, Fillingability pada mix design SCC dengan penambahan Superplasticizer jenis Conplast SP430 pada beton mutu normal.

b. Variabel Terikat

Kuat tekan beton yang dihasilkan setelah mengalami proses pemadatan beton dengan metode SCC menggunakan Superplasticizer Conplast SP430 pada beton mutu normal.

c. Variabel Kontrol

Pengaruh bahan tambahan Superplasticizer jenis Conplast SP430 pada Self Compacting Concrete (SCC) pada beton mutu normal terhadap Fillingability, Passingability dan kuat tekan

beton.

Tabel 1. Perhitungan total kebutuhan bahan tiap $0.0848 \mathrm{~m} 3$ benda uji

\begin{tabular}{llllll}
\hline \multicolumn{1}{c}{ Benda Uji } & Kerkil & Pasir & Semen & Complast & Air \\
\hline Normal & 62,65 & 93,94 & 30,27 & 0 & 19,08 \\
Penambahan Sp 0,5 Liter & 62,65 & 93,94 & 30,27 & 0,15 & 17,17 \\
Penambahan Sp 1 Liter & 62,65 & 93,94 & 30,27 & 0,30 & 17,17 \\
Penambahan Sp 1,5 Liter & 62,65 & 93,94 & 30,27 & 0,45 & 17,17 \\
Penambahan Sp 2 Liter & 62,65 & 93,94 & 30,27 & 0,61 & 17,17 \\
Total Kebutuhan Bahan & 313,26 & 469,68 & 151,33 & 1,51 & 87,75 \\
\hline
\end{tabular}




\section{HASIL PENGUJIAN DAN ANALISA}

Hasil pengujian pada penelitian ini terdiri dari dua bagian, yaitu beton segar dan beton keras. Pada saat dilakukan pengujian Fillingability dan Passingability pada beton segar, dilakukan pula pengematan visual pada campuran beton untuk melihat efek segregasi. Pada beton keras dilakukan pengujian terhadap kuat tekan beton yang dilakukan pada umur 7, 14, 21, 28 hari.

\section{Fillingability dan Passingability}

Dari hasil pengujian terlihat bahwa penggunaan Superplasticizer berjenis Conplast SP430 dengan variasi sebesar 0.5; $1 ; 1.5$; 2 Liter, maupun tanpa Conplast SP430 tidak menunjukan perbedaan tingkat Workabilitas yang signifikan pada campuran betonnya, karena dilihat dari penggunaan air dengan komposisi yang sama pada tahap variasinya dapat menghasilkan tingkat Workabilitas yang hampir sama pula. Tapi dapat diketahui bahwa dengan penggunaan Conplast SP430 yang relatif besar (2 liter) cenderung dapat meningkatkan tingkat Workabilitas beton, sedangkan penggunaan Conplast SP430 (0.5 liter) telah mampu memenuhi syarat dari Workabilitas beton dengan menggunakan Mix Design SCC. Hasil dari analisa dari pengaruh komposisi penambahan Conplast SP430 terhadap Fillingability dapat dilihat pada Tabel 2 dan gambar 5 :

Tabel 2. Hasil pengujian Conplast SP430 terhadap Fillingability

\begin{tabular}{cccc}
\hline No & $\begin{array}{c}\text { Prosentase } \\
\text { SP430 } \\
\text { (liter) }\end{array}$ & $\begin{array}{c}\text { SF50 } \\
\text { (detik) }\end{array}$ & $\begin{array}{c}\text { VFtime } \\
\text { (detik) }\end{array}$ \\
\hline 1 & 0 & 5.00 & 3.00 \\
2 & 0.5 & 3.40 & 2.80 \\
3 & 1 & 1.40 & 2.75 \\
4 & 1.5 & 1.20 & 2.68 \\
5 & 2 & 1.04 & 2.30 \\
\hline
\end{tabular}

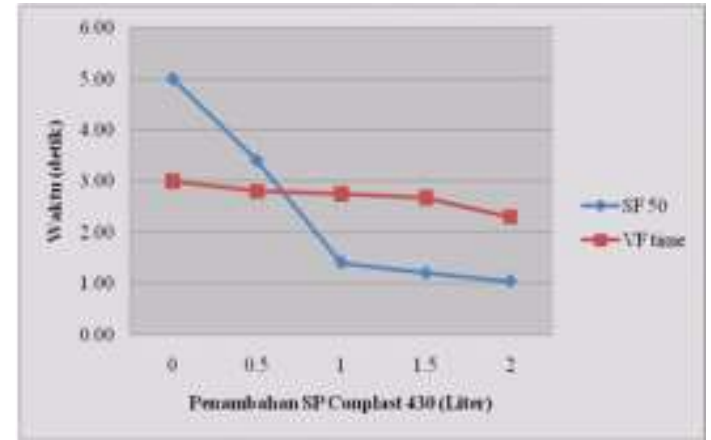

Gambar 5. Grafik pengaruh Conplast SP430 terhadap Fillingability

Dari pengujian Passingability yang sudah dilakukan, dapat diamat bahwa penggunaan Conplast SP430 mulai dari 0.5; 1; 1.5; 2 liter cukup berpengaruh terhadap Passingability dari campuran beton segar. Dalam hal ini campuran beton sudah dalam keadaan atau kondisi yang memenuhi standart sebagai Self Compacting Concrete yang amat baik dilihat dari nilai $\mathrm{H} 2 / \mathrm{H} 1$ yang memenuhi syarat. Sedangkan tingkat Flowability juga sangat baik, terlihat dari nilai $\mathrm{FL}_{40}$ dan $\mathrm{FL}_{\text {ujung }}$ yang rata-rata mencapai 1 dan 4 detik dengan komposisi pengurangan penggunaan air sebanyak $10 \%$ dari total volume air.

Dari hasil pengujian Passingability pada SCC, pengaruh komposisi penambahan Conplast SP430 terhadap Passingability dari campuran beton dapat dilihat dengan semakin besarnya penggunaan Conplast SP430 pada campuran beton maka akan menambah tingkat Passingability dari campuran beton tersebut. Untuk mengetahui tingkat Flowability dari campuran beton dengan lebih jelas dapat dilihat pada Tabel 3 dan gambar 6 :

Tabel 3. Hasil pengujian Conplast SP430 terhadap Passingability

\begin{tabular}{cccc}
\hline No & $\begin{array}{c}\text { Prosentase } \\
\text { SP430 } \\
\text { (liter) }\end{array}$ & $\begin{array}{c}\text { FL40 } \\
\text { (detik) }\end{array}$ & $\begin{array}{c}\text { FLujung } \\
\text { (detik) }\end{array}$ \\
\hline 1 & 0 & 3.30 & 4.20 \\
2 & 0.5 & 3.00 & 3.80 \\
3 & 1 & 2.60 & 3.20 \\
4 & 1.5 & 1.26 & 2.00 \\
5 & 2 & 1.00 & 1.20 \\
\hline
\end{tabular}




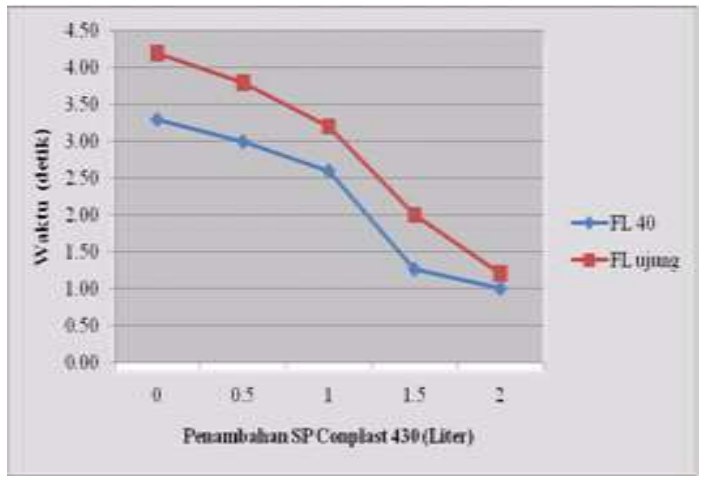

Gambar 6. Grafik pengaruh Conplast SP430 terhadap Passingability

Pengujian kuat tekan beton (Compression Test) merupakan pengujian beton keras dengan cara destruktif dimana pengujian berfungsi untuk mengetahui kuat tekan beton yang dihasilkan di setiap umur beton yang dikehendaki. Dalam variasi Mix Design digunakan beberapa variasi komposisi Conplast SP430, antara lain 0; $0.5 ; 1 ; 1.5 ; 2$ liter. Dari hasil yang didapatkan dapat dilihat bahwa Conplast SP430 dapat memberikan pengaruh cukup besar dalam peningkatan kekuatan atau mutu beton disetiap umur pengujiannya.

Penggunaan Conplast SP430 sebesar 1 liter didalam variasi Mix Design telah mampu memenuhi target kekuatan awal dan akhir yang diharapkan yaitu sebesar 312.88 $\mathrm{kg} / \mathrm{cm}^{2}$ pada umur beton 7 hari dan 356.82 $\mathrm{kg} / \mathrm{cm}^{2}$ pada umur 28 hari. Sedangkan pada variasi yang tidak menggunakan Conplast SP430, target kekuatan awal beton telah mampu memenuhi yaitu $198.63 \mathrm{~kg} / \mathrm{cm}^{2}$ pada umur 7 hari dan $281.24 \mathrm{~kg} / \mathrm{cm}^{2}$ pada umur 28 hari. Penggunaan Conplast SP430 sebesar 0,5 liter didalam variasi Mix Design telah mampu memenuhi target kekuatan awal dan akhir yang diharapkan yaitu sebesar $209.17 \mathrm{~kg} / \mathrm{cm}^{2}$ pada umur beton 7 hari dan $290.03 \mathrm{~kg} / \mathrm{cm}^{2}$ pada umur 28 hari.

Penggunaan Conplast SP430 sebesar 1.5 liter didalam variasi Mix Design telah mampu memenuhi target kekuatan awal dan akhir yang diharapkan yaitu sebesar 228.51 $\mathrm{kg} / \mathrm{cm}^{2}$ pada umur beton 7 hari dan 311.12 $\mathrm{kg} / \mathrm{cm}^{2}$ pada umur 28 hari. Sedangkan penggunaan Conplast SP430 sebesar 2 liter didalam variasi Mix Design telah mampu memenuhi target kekuatan awal dan akhir yang diharapkan yaitu sebesar 195.11 $\mathrm{kg} / \mathrm{cm}^{2}$ pada umur beton 7 hari dan 288.27 $\mathrm{kg} / \mathrm{cm}^{2}$ pada umur 28 hari.

Target yang diharapkan sudah tercapai dengan baik. Dari penjelasan diatas, didapat bervariasi kuat tekan yang dihasilkan dari penambahan Conplast SP430 yang berbeda-beda. Grafik dari kuat tekan terhadap variasi penambahan Conplast SP430 dapat dilihat pada gambar 7 .

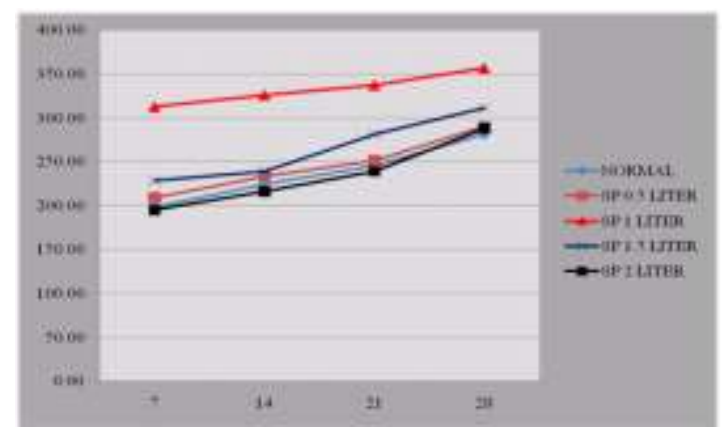

Gambar 7. Grafik dari kuat tekan terhadap penambahan Conplast SP430

\section{SIMPULAN}

Berdasarkan hasil penelitian tentang Analisis Penggunaan Dan Penerapan Metode Self Compacting Concrete (SCC) Pada Beton Mutu Normal, pengaruh yang ditimbulkan akibat penambahan zat additive Conplast SP430 dari berat semen per $100 \mathrm{~kg}$ terlihat dari Workability maupun kuat tekan beton yang dihasilkan antara lain sebagai berikut :

1. Benda uji silinder beton yang dibuat sebagai kontrol, dalam penelitian yaitu tanpa penambahan Superplasticizer Conplast SP430 dari berat semen telah melebihi kuat tekan yang direncanakan yaitu $250 \mathrm{~kg} / \mathrm{cm}^{2}$. Sedangkan proporsi semen untuk per $1 \mathrm{~m} 3$ campuran beton sebanyak $357 \mathrm{~kg} / \mathrm{m}^{3}$, pasir $1108 \mathrm{~kg} / \mathrm{m}^{3}$, agregat kasar $739 \mathrm{~kg} / \mathrm{m}^{3}$, dan air $225 \mathrm{~kg}$. sedangkan untuk tiap $0.0848 \mathrm{~m} 3,30.27$ $\mathrm{kg} / \mathrm{m} 3$ berat semen, $93.94 \mathrm{~kg} / \mathrm{m} 3$ berat agregat halus, $62.65 \mathrm{~kg} / \mathrm{m} 3$, dan $19.08 \mathrm{~kg}$ untuk campuran beton tanpa penambahan Conplast SP430 sedangkan untuk berat air yang menggunakan Conplast SP430 ada pengurangan berat air $10 \%$ dari total berat air per $\mathrm{m} 3$ yaitu sebanyak $17.17 \mathrm{~kg}$.

2. Semakin banyak penambahan Conplast SP430 tingkat Workability pada campuran beton akan semakin baik. Penambahan Superplasticizer Conplast SP430 sebanyak 2 liter lebih memenuhi syarat Self Compacting pada campuran beton. Pada Mix Design SCC tanpa penambahan Conplast SP430 tidak terjadi penurunan tingkat Fillingability, Passingability pada campuran beton dikarenakan perbandingan agregat halus $60 \%$ dari total volume beton sedangkan 
untuk agregat kasar hanya $40 \%$ dari total volume beton.

3. Penambahan Superplasticizer Conplast SP430 dapat menyebabkan bertambahnya kekuatan tekan beton hal ini disebabkan karena Conplast SP430 yang lebih cepat mengurangi kadar air dalam campuran beton dan mampu lebih cepat mengeras dari pada beton yang tidak menggunakan campuran Conplast SP430. Namun tidak selamanya penambahan Conplast SP430 dapat meningkatkan kuat tekan pada beton. Pada penambahan 2 liter Conplast SP430 pada umur 28 hari kuat tekan beton akan turun sebanyak $24.38 \%$ dari kuat tekan beton dengan penambahan Conplast SP430 sebanyak 1 liter. Dari penambahan Conplast SP430 yang mempunyai kekuatan beton tinggi adalah penambahan Conplast SP430 sebanyak 1 liter dengan kekuatan akhir pada beton yang dihasilkan sebesar $356.82 \mathrm{~kg} / \mathrm{cm}^{2}$.

4. Dalam penggunaan SCC dapat meningkatkan Workability pada campuran beton sehingga lebih memudahkan dalam proses pengecoran beton ke dalam bekisting. Tetapi dalam penggunaan SCC harus lebih diperhatikan pada pembuatan bekisting karena encernya campuran beton dengan menggunakan SCC dan jika bekisting tidak rapat akan menyebabkan pengurangan f.a.s dalam campuran beton yang dapat menurunkan kekuatan tekan pada beton tersebut.

\section{DAFTAR PUSTAKA}

Anonim, Departemen Pekerjaan Umum, (SKSNI) T-15-1990-03 Tata Cara Pembuatan Rencana Campuran Beton Normal. Bandung : Penerbit Yayasan LPMB.

Anonim, Departemen Pekerjaan Umum, SNI 03-1974-1990. Metode Pengujian Kuat Tekan Beton. Bandung : Penerbit Yayasan LPMB.

Anonim, Departemen Pekerjaan Umum, SNI 03-2493-1991. Metode Pembuatan Dan Perawatan Benda Uji Beton Di Laboratorium. Bandung : Penerbit Yayasan LPMB.

Efnarc Association, Spesification and Guideliness for Self Compacting Concrete, 2002

Fosroc Indonesia. 2006/2007. Product catalogue.

G. De. Schutter. 2005. Guidelines For Testing Fresh SELF COMPACTING CONCRETE. Japan.

Setiawan, A., Self Compacting Concrete: Fenomena Baru Dunia Teknologi Beton, 2001

Sugiarto, Handoko. 2006. Peningkatan Kekuatan Awal Beton Pada Self Compacting Concrete. Penelitian Universitas Petra : Surabaya. 